This Section of Epidemiology and Psychiatric Sciences appears in each issue of the Journal and is dedicated to all forms of creative production born of an intimate and individual urge, often secretive, unbound from the conventional art system rules. Through short descriptions of the Outsider art work of prominent artists and new protagonists often hosted in community mental health services, this section intends to investigate the latest developments of the contemporary art scene, where the distances between the edge and the center are becoming more and more vague.

Carole Tansella, Section Editor

\title{
Outsider Art from Japan
}

\section{S. Sharmacharja}

Wellcome Collection, 183 Euston Road, London, NW1 2BE, United Kingdom and Northern Ireland

Received 7 June 2016; Accepted 7 June 2016

Key words: Autism, contemporary art, community mental health, mental health, multicultural.

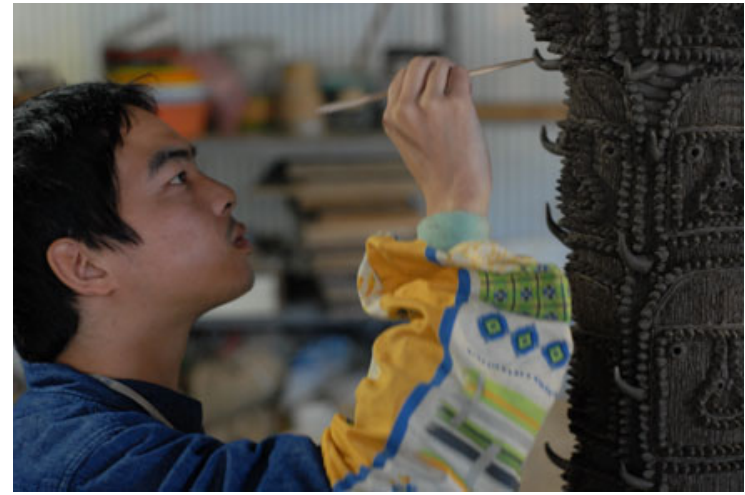

Image of artist at work in studio, (c) Shinichi Sawada, Photo by Nobuo Onishi

In 2013 I curated Souzou: Outsider Art from Japan at Wellcome Collection, London. This exhibition consisted of some 300 work, created by 46 service users of Japan's social welfare system who have been diagnosed as having learning difficulties or psychiatric conditions. 'Souzou' is a Japanese word that has a dual meaning depending on how it is written, 創造 signifies creation, whereas 想像, imagination. Both allude to a force by which new ideas are born and take form in the world.

Address for correspondence: Wellcome Collection, 183 Euston Road, London, NW1 2BE, United Kingdom and Northern Ireland.

(Email: info@wellcomecollection.org)

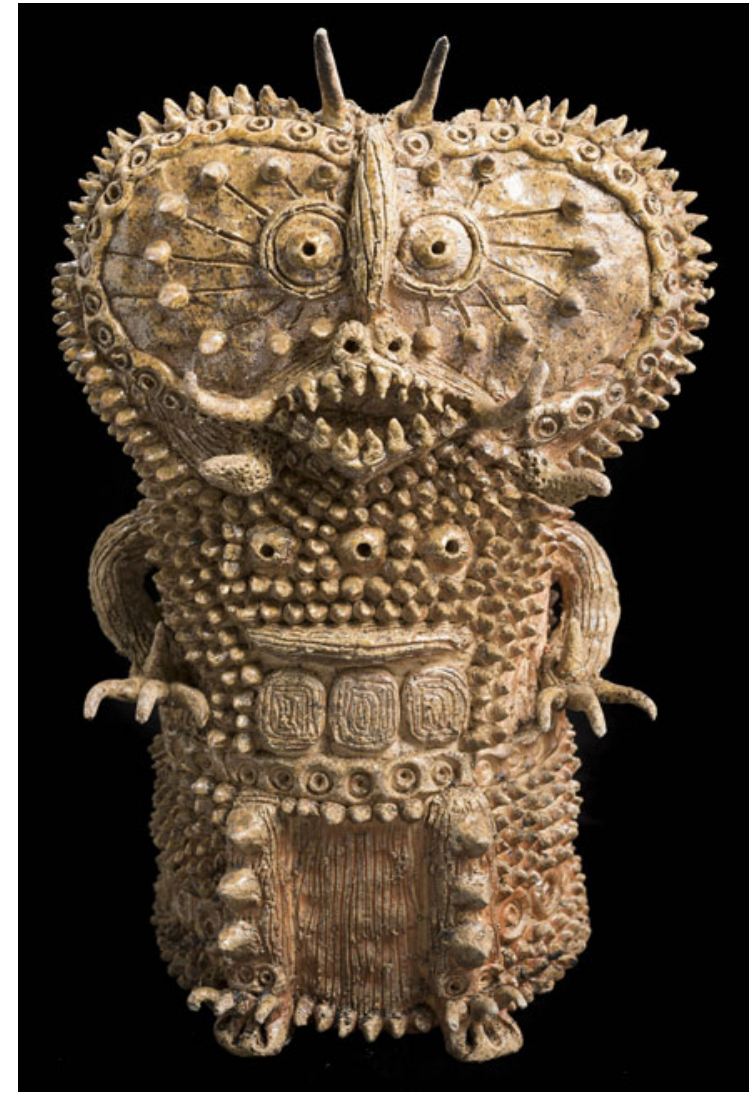

Shinichi Sawada, Untitled, 2006-10, Private Collection, Image (C) Wellcome Collection 
Souzou was one of the three major exhibitions that took place in Europe that year which showcased the work of artists traditionally described as 'outsider'. All three were remarkable in that they presented objects not in terms of the context in which they were made, enshrouded by the maker's biography or medical diagnoses, but as artworks in their own right, capable of saying something meaningful about human experience and the world around us.

London's Hayward Gallery presented The Alternative Guide to the Universe, a compendium of self-taught artists from across the globe who systemically invent personal mythologies and worlds within worlds in order to recode reality. International curator Massimiliano Gioni's edition of the Venice Biennale- representing the apotheosis of contemporary art - likewise looked towards the works of the unknown and unschooled in The Encyclopedic Palace. This varied selection offered different possibilities in understanding ourselves in relation to the wider world. The simultaneity of the three shows bespeak a western weariness with the elite contemporary art world, the morass of the commercial art market and ever hierarchical nature of art institutions. Instead inspiration is sought in looking toward works created by visionaries, whose purity of content is deemed to be unconfined by such parameters.

One such artist is Shinichi Sawada, whose work featured prevalently in both Souzou and The Encyclopedic Palace. Born in 1987 in Shiga, Japan, Sawada has autism and rarely speaks. He creates fantastical clay beings, a cosmos inhabited by daemons, reptilian beasts and ocean dwelling creatures. These mythical beings are patiently formed using hundreds of handmade spikes in an inimitable style which has become Sawada's signature. His practice is not linked to any known tradition despite ceramics being such an integral medium in Japanese art history.

Sawada works alone, in a studio high up in the mountains of the Shiga prefecture, which is maintained by a local day care social welfare facility for people with mental health difficulties. It was while attending this institution that Sawada found an affinity with the art form. Supported by a carer who helps him to fire his works in the huge kilns, Sawada works in serial, creating an original form and then repeating it faithfully over and over again. When I went to visit his studio, Sawada worked with a quiet intensity, speaking only to identify the general classifications he designated each work to - sea urchin and beaver, daemon and dragon.

Sawada's refusal to further embellish explanation of his work infuriates art critics and historians globally, who try to find meaning through a known frame of reference. Allusions have been made to Japanese folklore, Noh theatre, manga cartoon and even African masks, but as art critic Chris Wiley finally admits in his conclusion to his entry in the Venice Biennale catalogue: 'Of course, their true nature, and place in his individual cosmology, may never be known. Nevertheless they stand as evocative and enigmatic testaments to his inner life, mute idols of a tribe of one' (Wiley, 2013).

As with all of the artists profiled in Souzou, Sawada's work is not for sale. This is because it is facilitated by Japan's highly developed social welfare system. This, as in Britain, was initiated post 1945 following the Second World War. However, Art Brut or 'raw art' (Rhodes, 2000) as it is more commonly termed in Japan, followed a different trajectory to that in Europe. Instead of representing an anti-establishment ideology as espoused by French artist Jean Dubuffet and his contemporaries, Outsider Art was and remains aligned with public health and educational reform.

Educationalist pioneers such as Kazuo Itoga paved the way for the production of personal artworks within an institutional context. In 1947 he founded Omi Gakuen, the first facility for war orphans, many of who suffered both mental and physical trauma. Revolutionary for its time, it offered a free form syllabus encompassing art, which was non-interventionist in its methodology - allowing access to materials so its students could create what they wanted without training or direction.

As a result, this form of artistic practice has remained firmly embedded in the domain of social care rather than being integrated into an alternative art circuit with a collector base as in Europe. Sawada's work however has been garnering ever growing interest in Europe, with his work entering public collections such as the Collection de la Art Brut, Lausanne as well as featuring in high profile exhibitions such as the Venice Biennale. It will be interesting to see whether the mounting interest in outsider art from outside Japan means these two trajectories will collide and what that will mean for outsider artists such as Sawada as a result.

\section{Conflict of Interest}

None.

\section{References}

Rhodes C (2000). Outsider Art: Spontaneous Alternatives.

Thames and Hudson: London.

Wiley C (2013). The Encyclopedic Palace. Exhibition Catalogue, 1 June - 24 November 2013. La Biennale di Venezia, Marsilio: Venezia. 


\section{About the author}

Shamita Sharmacharja is a curator of Temporary Exhibitions at Wellcome Collection, London where she curated Souzou: Outsider Art from Japan (2013) and was co-curator of Forensics: An Anatomy of Crime (2015). Prior to working at Wellcome Collection she took part in the Inspire Curatorial Fellowship scheme run by the Arts Council England, and worked in the Exhibitions team of the internationally renowned contemporary art space, Whitechapel Gallery, London. There she delivered a wide array of ambitious exhibitions, including Inner Worlds Outside (2006) - a large survey show that examined the impact that outsider artists had on modernism in 20th century Europe. She also worked as an Assistant Curator at Tate Modern, London, in the Learning Department, where she worked with artists and a diverse range of school and community groups, which included people with physical and learning disabilities and behavioural conditions. She is currently working on an exhibition about graphic design and its interface with public health forthcoming at Wellcome Collection in 2017.

Carole Tansella, Section Editor 